\title{
Activation of the CD95 (APO-1/Fas) pathway in drug- and $\gamma$-irradiation-induced apoptosis of brain tumor cells
}

\author{
Simone Fulda ${ }^{1}$, Carsten Scaffidi ${ }^{2}$, Torsten Pietsch ${ }^{3}$, \\ Peter H. Krammer ${ }^{2}$, Marcus E. Peter ${ }^{2}$ and \\ Klaus-Michael Debatin ${ }^{1,4}$ \\ 1 University Children's Hospital, Prittwitzstr. 43, D-89075 Ulm, Germany \\ 2 Division of Immunogenetics, German Cancer Research Center, Im \\ Neuenheimer Feld 280, D-69120 Heidelberg, Germany \\ ${ }^{3}$ Department of Neuropathology, University of Bonn Medical Center, D-53105 \\ Bonn, Germany \\ 4 corresponding author: K.-M. Debatin, tel: +49-731 502 7700; fax: +49- \\ 731502 6681; e-mail: klaus-michael.debatin@medizin.uni-ulm.de
}

Received 8.4.98; revised 7.5.98; accepted 15.5.98

Edited by M. Piacentini

\begin{abstract}
Chemotherapeutic agents and $\gamma$-irradiation used in the treatment of brain tumors, the most common solid tumors of childhood, have been shown to act primarily by inducing apoptosis. Here, we report that activation of the CD95 pathway was involved in drug- and $\gamma$-irradiation-induced apoptosis of medulloblastoma and glioblastoma cells. Upon treatment CD95 ligand (CD95-L) was induced that stimulated the CD95 pathway by crosslinking CD95 via an autocrine/paracrine loop. Blocking $\mathrm{CD} 95-\mathrm{L} /$ receptor interaction using $\mathrm{F}\left(\mathrm{ab}^{\prime}\right)_{2}$ antiCD95 antibody fragments strongly reduced apoptosis. Apoptosis depended on activation of caspases (interleukin $1 \beta$-converting enzyme/Ced-3 like proteases) as it was almost completely abrograted by the broad range caspase inhibitor benzyloxycarbonyl-Val-Ala-Asp-fluoromethyl ketone. Apoptosis was mediated by cleavage of the receptor proximal caspase FLICE/MACH (caspase-8) and the downstream caspase CPP32 (caspase-3, Apopain) resulting in cleavage of the prototype caspase substrate PARP. Moreover, CD95 was upregulated in wild-type p53 cells thereby increasing responsiveness towards CD95 triggering. Since activation of the CD95 system upon treatment was also found in primary medulloblastoma cells ex vivo, these findings may have implications to define chemosensitivity and to develop novel therapeutic strategies in the management of malignant brain tumors.
\end{abstract}

Keywords: apoptosis; brain tumors; drugs; $\gamma$-irradiation; CD95 (APO-1/Fas)

Abbreviations: CD95-L, CD95 ligand; DDP, cisplatinum; Doxo, doxorubicin; ICE, interleukin $1 \beta$-converting enzyme; PARP, poly(ADP-ribose) polymerase; zVAD-fmk, benzyloxycarbonyl-ValAla-Asp-fluoromethyl ketone

\section{Introduction}

Tumors of the central nervous system are the most frequent solid malignancies of childhood (Stevens et al, 1991). Although medulloblastoma often initially respond to chemotherapy and irradiation, glioblastoma are largely resistant to current treatment approaches and the overall prognosis of patients with this malignancy has not substantially improved for many years (Deen et al, 1993; Friedman et al, 1991). Malignant growth has been recognized to result not only from enhanced cell proliferation, but also from decreased programmed cell death (Thompson, 1995). Apoptosis pathways may be disrupted in tumor cells conferring a survival advantage (Thompson, 1995). Chemotherapeutic agents irrespective of their intracellular target and radiation have been shown to cause cell death by inducing apoptosis in sensitive target cells (Fisher, 1994; Meyn et al, 1996). However, the precise molecular mechanisms regulating therapy-induced apoptosis in brain tumor cells have not yet been defined. Insights into these mechanisms may be crucial for the development of novel treatment strategies that enhance or restore the ability of cancer cells to undergo therapy-induced cell death.

Cell surface receptor molecules of the tumor necrosis factor/nerve growth factor (TNF/NGF) receptor superfamily such as CD95 (APO-1/Fas) are involved in regulation of apoptosis (Debatin, 1996; Trauth et al, 1989; Oehm et al, 1992; Nagata, 1997). Triggering of CD95 by crosslinking either with its specific ligand or with an agonistic antiCD95 antibody rapidly induces apoptosis in vitro and in vivo in sensitive cells by activating a death signaling cascade (Peter et al, 1996). Upon crosslinking, CD95 recruits FADD/MORT-1 and FLICE/MACH (caspase 8), a member of the caspase family (ICE/Ced-3 like proteases), into a death-inducing signaling complex (DISC) (Kischkel et al, 1995; Muzio et al, 1996; Medema et al, 1997). FLICE considered to be the most upstream component of the caspase cascade during death receptor-mediated apoptosis is activated upon recruitment to the DISC and catalyzes cleavage of downstream members of the caspase family leading to proteolysis of substrates such as the nuclear enzyme poly(ADP-ribose) polymerase and ultimately to cell death (Medema et al, 1997). Although CD95 is expressed on a variety of normal and neoplastic cells including malignant glioma cells (Weller et al, 1994), the key role of the CD95 pathway in negative growth regulation has mostly been studied within the immune system (Krammer et al, 1994). CD95-L is a $40 \mathrm{kDa}$ type II transmembrane molecule of the corresponding TNF/NGF family of ligands which may also occur in a soluble form released from the cell surface by proteolytic cleavage (Suda et al, 1993; Tanaka et al, 1995). CD95-L is upregulated in activated T-cells and is crucial for maintenance of homeostasis within the immune system, 
e.g. by eliminating peripheral T-cells following an immune response (Dhein et al, 1995).

We and others recently identified the CD95 ligand/ receptor system as a key mediator of drug-induced apoptosis in leukemia and solid tumor cells (Friesen et al, 1996; Fulda et al, 1997; Mueller et al, 1997). Similar to apoptosis in activated T-cells, CD95-L was induced upon treatment with cytotoxic drugs and triggered cell death in an autocrine or paracrine manner via crosslinking of CD95 (Friesen et al, 1996; Fulda et al, 1997). In addition, treatment with cytotoxic drugs resulted in upregulation of CD95 (Fulda et al, 1997; Debatin, 1997; Micheau et al, 1997; Mueller et al, 1997). In the present study, we investigated the molecular requirements for apoptosis in response to anticancer drugs and $\gamma$-irradiation in medulloblastoma and glioblastoma cell lines and in ex vivo-derived primary tumor cells.

\section{Results}

\section{Drug- and $\gamma$-irradiation-induced apoptosis}

Following drug treatment of $\gamma$-irradiation medulloblastoma and glioblastoma cells showed morphological alterations typical of cells undergoing apoptosis such as shrinkage, membrane blebbing and nuclear condensation as assessed by light microscopy and DAPI-staining (data not shown). Propidium iodide staining and FACS analysis were performed for dose response experiments. Doxorubicin and $\gamma$-irradiation rapidly induced apoptosis in D283 Med and Daoy medulloblastoma cells compared to A172 glioblastoma cells which showed a more delayed response (Figure 1). Other cytotoxic drugs used in the treatment of brain tumors such as cisplatinum, VP-16, vincristine and cytarabine similarly triggered apoptosis in these cell lines (data not shown). In addition to propidium iodide staining, analysis of apoptosis by annexin $\mathrm{V}$ staining revealed similar results (data not shown). These data show that cytotoxic drugs and $\gamma$-irradiation, therapeutic interventions used for the treatment of brain tumors in vivo, caused apoptotic death in target cells in vitro.

\section{Activation of caspases}

To gain insight into the molecular requirements of drug- and $\gamma$-irradiation-induced apoptosis we investigated whether caspases (ICE/Ced-3 like proteases) involved as effector molecules in various death signaling pathways were activated upon treatment. To assess activation of caspases we monitored cleavage of the nuclear enzyme poly(ADP) ribose polymerase (PARP), one of the known substrates of caspases (Teweri et al. 1995) by Western blot analysis. Following incubation with doxorubicin and $\gamma$-irradiation PARP was proteolytically processed to its characteristic $85 \mathrm{kDa}$ fragment (Figure 2A). Kinetics of PARP cleavage corresponded to kinetics of apoptosis induction as D283 Med cells which rapidly underwent apoptosis also rapidly processed PARP upon doxorubicin treatment (Figure 2A). The delayed kinetics of apoptosis induction in A172 glioblastoma cells was reflected by delayed detection of cleaved products of PARP (Figure 2A).

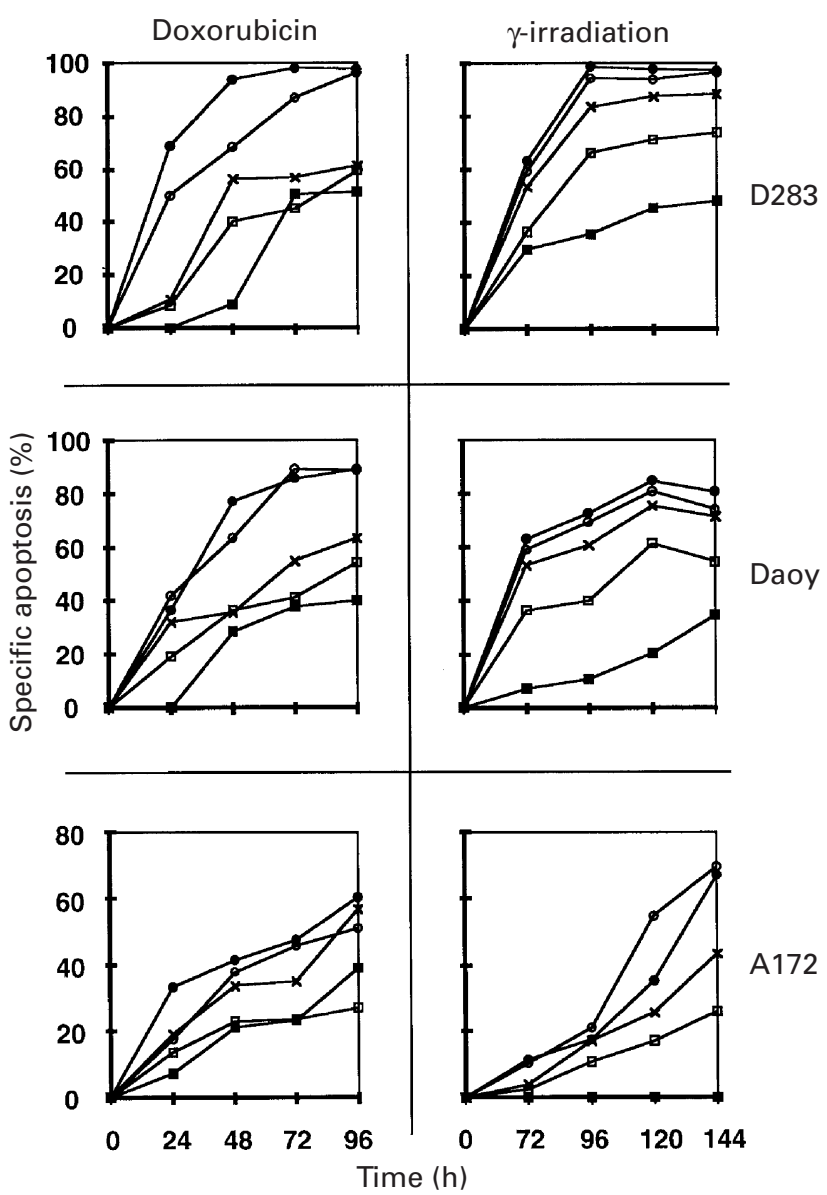

Figure 1 Drug- and $\gamma$-irradiation-induced apoptosis. Apoptosis of medulloblastoma (D283 Med, Daoy) and glioblastoma (A172) cells was determined by FACS analysis of propidium iodide stained nuclei after treatment with doxorubicin or $\gamma$-irradiation at concentrations and for time points indicated (doxorubicin: $\mathbf{\square}, 0.01 \mu \mathrm{g} / \mathrm{ml}^{-1} ; \square, 0.05 \mu \mathrm{g} / \mathrm{ml}^{-1} ; \times, 0.1 \mu \mathrm{g} / \mathrm{ml}^{-1} ; 0,0.5 \mu \mathrm{g}$ ) $\mathrm{ml}^{-1}$;, $1 \mu \mathrm{g} \mathrm{ml}^{-1} ; \gamma$-irradiation: $\mathbf{0}, 3 \mathrm{~Gy} ; \square, 10 \mathrm{~Gy} ; \times, 30 \mathrm{~Gy} ; \bigcirc, 60 \mathrm{~Gy} ;$ $100 \mathrm{~Gy})$. Percentage of specific apoptosis was calculated as follows: $100 \times$ (experimental apoptosis (\%) - spontaneous apoptosis $(\%) / 100 \%$ spontaneous apoptosis (\%)). Data are the mean of triplicates with standard deviations of less than $10 \%$. Similar results were obtained in three separate experiments

To assess different components of the caspase cascade activation of the CD95 receptor-proximal caspase FLICE and the downstream caspase CPP32 was monitored. Upon drug incubation and $\gamma$-irradiation full length FLICE, which exists in two isoforms (caspase 8/a and 8/b; Scaffidi et al, 1997), was cleaved into the p43 and p41 intermediate fragments derived from the two isoforms of FLICE, respectively, and to the p18 active subunits (Figure 2B). In addition, CPP32 was proteolytically processed to its active subunits (Figure 2B). Incubation with the broad spectrum peptide inhibitor of caspases zVAD-fmk almost completely inhibited doxorubicin- and $\gamma$-irradiation-induced apoptosis (Figure 2C) and blocked cleavage of FLICE and PARP (Figure 2D) suggesting that caspases were central to treatment-induced apoptosis. To test whether doxorubicin-induced activation of caspases and apoptosis depended on protein synthesis cells were incubated with cyclohex- 
A

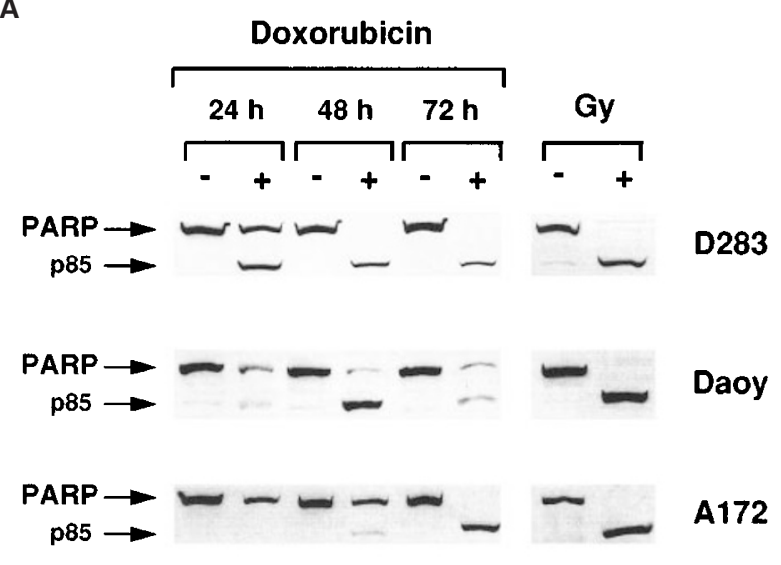

D

B

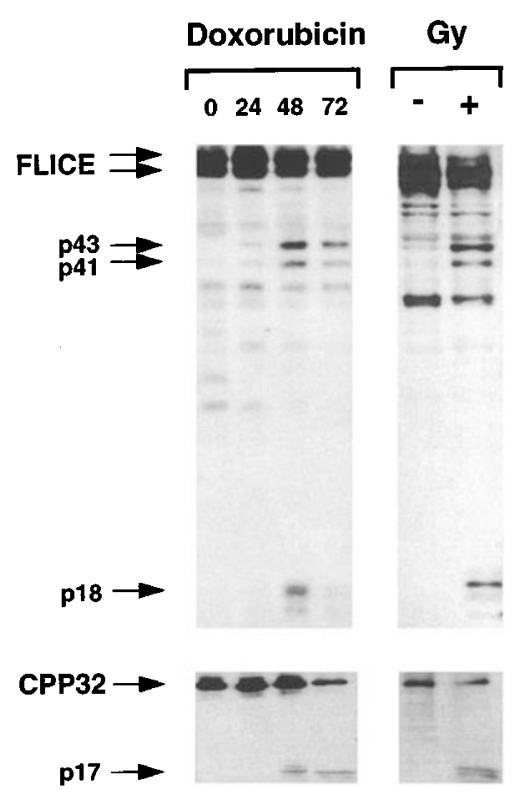

C

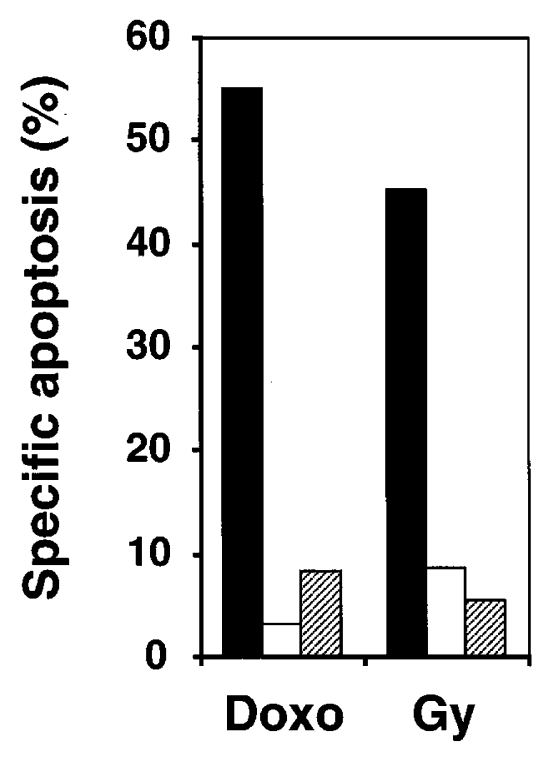

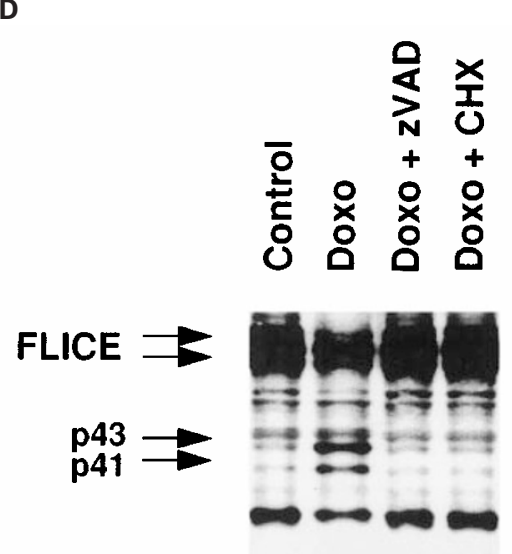
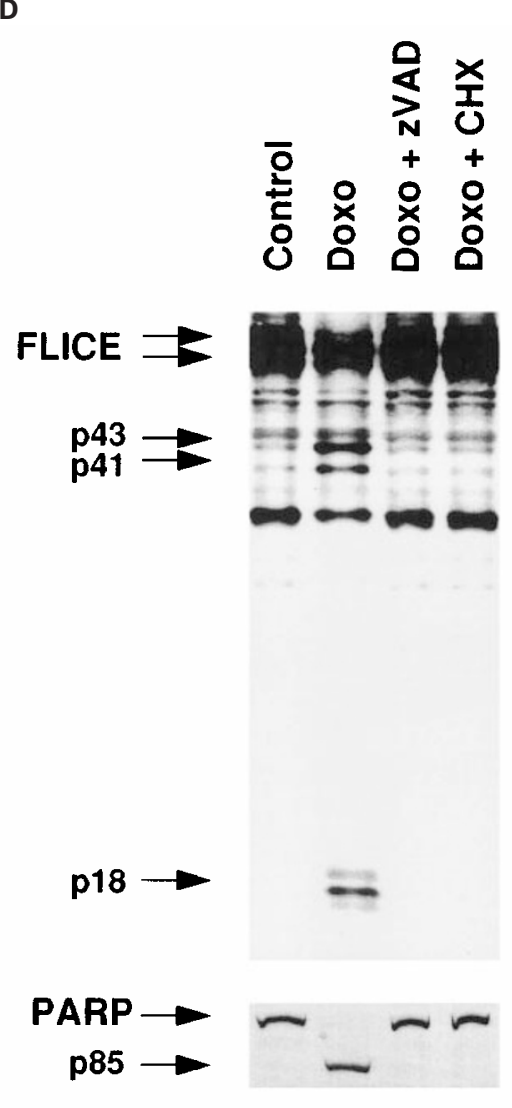
imide $(\mathrm{CHX})$ prior to treatment with doxorubicin. Doxorubicin- and $\gamma$-irradiation-triggered apoptosis and cleavage of FLICE and PARP was inhibited by incubation with cycloheximide (Figure 2C and D) indicating that treatment-induced apoptosis required protein synthesis. Taken together, these findings suggest that caspases were centrally involved in mediating cell death following drug treatment and $\gamma$-irradiation of brain tumor cells.

\section{Induction of CD95-L}

Activation of FLICE has been observed in response to CD95 triggering by recruitment of FLICE to the activated CD95 DISC (Medema et al, 1997). To investigate whether CD95 triggering might account for FLICE activation in our system we first analyzed CD95 expression and sensitivity to CD95 triggered apoptosis. All cell lines expressed moderate levels of CD95 and underwent apoptosis upon incubation with an agonistic anti-APO-1 (anti-CD95) antibody and cycloheximide indicating that the CD95 signaling pathway was intact in these cells (data not shown).

We next asked whether CD95-L was upregulated upon treatment and triggered the CD95 signaling pathway by crosslinking its cognate receptor. Incubation with doxorubicin or $\gamma$-irradiation caused induction of CD95-L mRNA and protein as assessed by RT-PCR and Western blot analysis, respectively (Figure $3 \mathrm{~A}$ ). To test whether CD95 ligand/receptor interaction were involved in triggering apoptosis blocking experiments were performed. Blockade of CD95 using $\mathrm{F}\left(\mathrm{ab}^{\prime}\right)_{2}$ anti-APO-1 antibody fragments, which have been described to interfere with CD95 ligand/receptor interaction (Dhein et al, 1995; Friesen et al, 1996), strongly reduced apoptosis (Figure $3 \mathrm{~B}$ ). This indicated that treatment-induced apoptosis in brain tumor cells was, at least in part, mediated via the CD95 ligand/receptor system.

\section{Upregulation of CD95}

CD95 expression has previously been reported to be upregulated upon drug treatment in wild-type p53 cells (Fulda et al, 1997; Debatin, 1997; Michaeu et al, 1997; Owen-Schaub et al, 1995; Mueller et al, 1997). Treatment with cisplatinum or $\gamma$-irradiation stimulated CD95 expression in wild-type p53 cells (D283 Med, A172), but not in p53 mutant cells (Daoy) as assessed by FACS analysis (Figure 4A). Increased expression of CD95 protein was also found by Western blot analysis (Figure 4B). CD95 mRNA was induced in cells with wild-type p53 (D283 Med, A172), but not in p53 mutant Daoy cells indicating that upregulation of CD95 protein resulted from increased mRNA levels (Figure 4B). P53 accumulated in wild-type p53 cells prior to upregulation of CD95 after drug treatment and $\gamma$-irradiation apoptosis (Figure
A

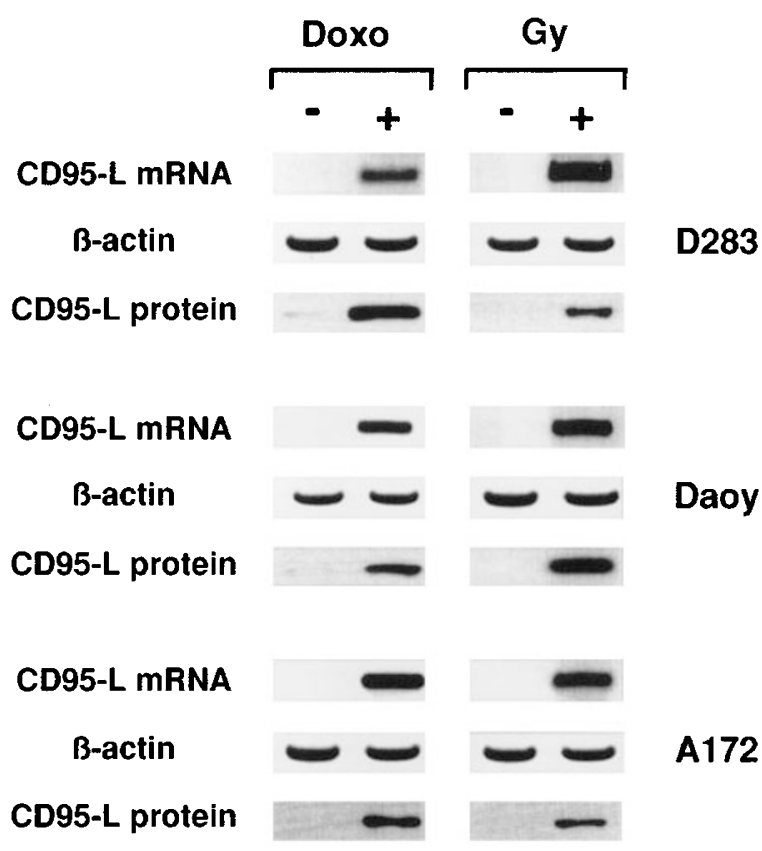

B

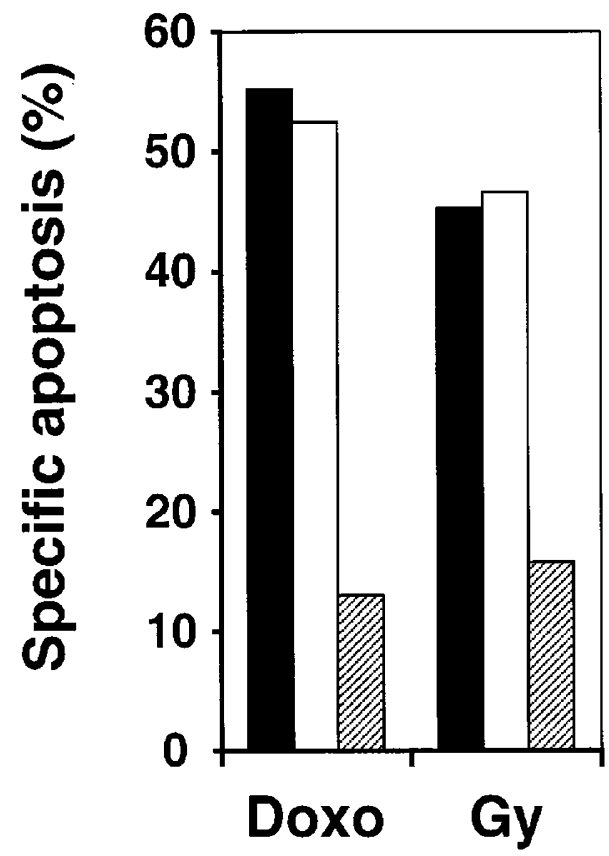

Figure 3 Induction of CD95 ligand. (A) Analysis of CD95-L mRNA and protein. Medulloblastoma (D283 Med, Daoy) and glioblastoma (A172) cells were treated (+) with $0.5 \mu \mathrm{g} \mathrm{ml}^{-1}$ doxorubicin for $24 \mathrm{~h}$ (Doxo) or $30 \mathrm{~Gy}$ for $72 \mathrm{~h}$ (Gy). CD95-L mRNA expression was determined by RT-PCR. CD95-L protein expression was analyzed by Western blot. $40 \mu \mathrm{g}$ protein of cell lysates per lane were separated by $12 \%$ SDS-PAGE. Immunodetection of CD $95-L$ protein was performed by mouse anti-CD95-L monoclonal antibody and ECL. (B) Inhibition of drug- and $\gamma$-irradiation-induced apoptosis by $\mathrm{F}\left(\mathrm{ab}^{\prime}\right)_{2}$ anti-APO-1 antibody fragments. Daoy medulloblastoma cells were treated for $48 \mathrm{~h}$ with $0.5 \mu \mathrm{g} \mathrm{ml}^{-1}$ doxorubicin (Doxo) or for $72 \mathrm{~h}$ with $30 \mathrm{~Gy}$ (Gy) after preincubation for $1 \mathrm{~h}$ with medium (black bars), $10 \mu \mathrm{g} \mathrm{ml} \mathrm{F}\left(\mathrm{ab}^{\prime}\right)_{2} \mathrm{Fll} 23$ (white bars) or $10 \mu \mathrm{g} \mathrm{ml}^{-1} \mathrm{~F}\left(\mathrm{ab}^{\prime}\right)_{2}$ anti-APO-1 (anti-CD95) antibody fragments (hatched bars). Apoptosis was determined by FACS analysis of propidium iodide stained nuclei. Specific apoptosis was calculated as described in Figure 1. Data are given as mean from three independent experiments done in triplicates. Standard deviations were less than $10 \%$ 
4C) suggesting that p53 might be involved in upregulation of CD95.

We then asked whether upregulation of CD95 expression would lead to increased responsiveness towards antiCD95-induced apoptosis. Treatment of cells haboring wildtype p53 with cisplatinum or $\gamma$-irradiation prior to addition of anti-APO-1 (anti-CD95) resulted in enhanced apoptosis compared to anti-APO-1 treatment alone, which had only a minimal effect in the absence of cycloheximide (Figure 4D). In contrast, p53 mutant Daoy cells could not be sensitized towards anti-CD95 triggering by preincubation with cisplatinum or by $\gamma$-irradiation (Figure 4D). These experiments demonstrated that drug incubation and $\gamma$-irradiation enhanced CD95 expression in cells with wild-type p53 thereby rendering these cells more susceptible towards anti-CD95-triggered apoptosis.

\section{Drug-induced apoptosis in ex vivo-derived medulloblastoma cells}

To assess whether or not our findings were restricted to longterm cultured cell lines, we analyzed drug-induced apoptosis in an ex vivo-derived fresh medulloblastoma tumor specimen. Primary medulloblastoma cells were highly sensitive to treatment with doxorubicin (Figure 5A). Upon incubation with doxorubicin expression of CD95-L mRNA and CD95-L protein
A

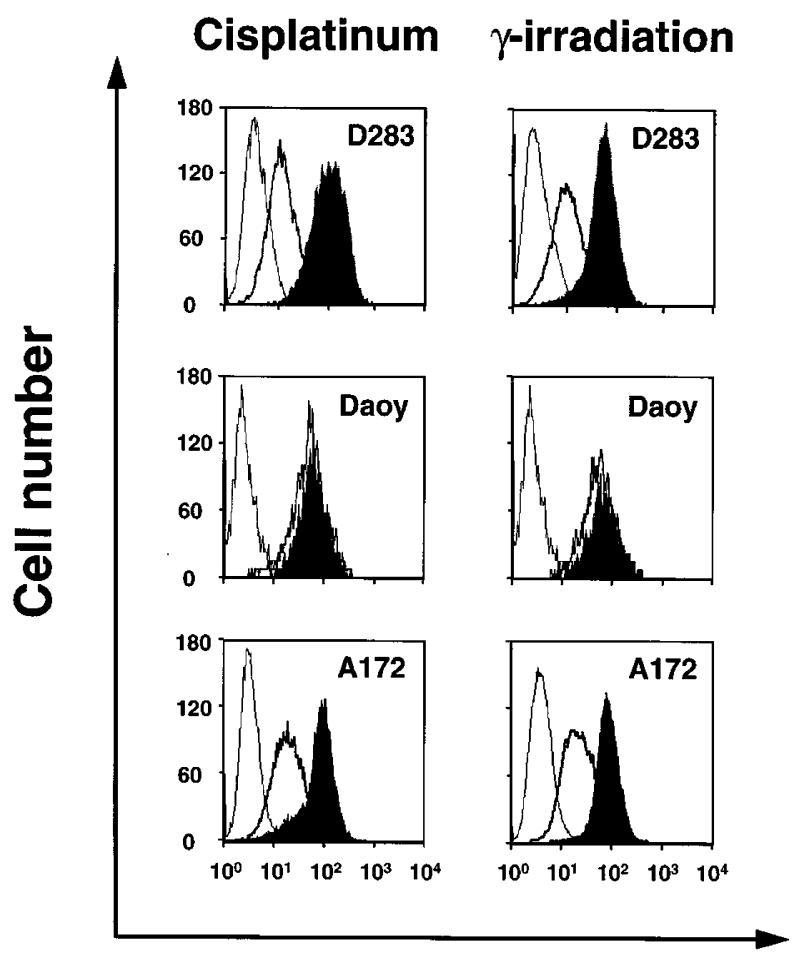

Fluorescence intensity

C

Cisplatinum

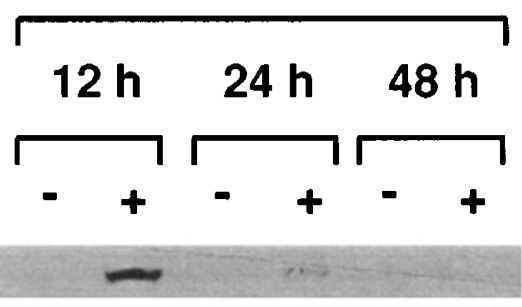

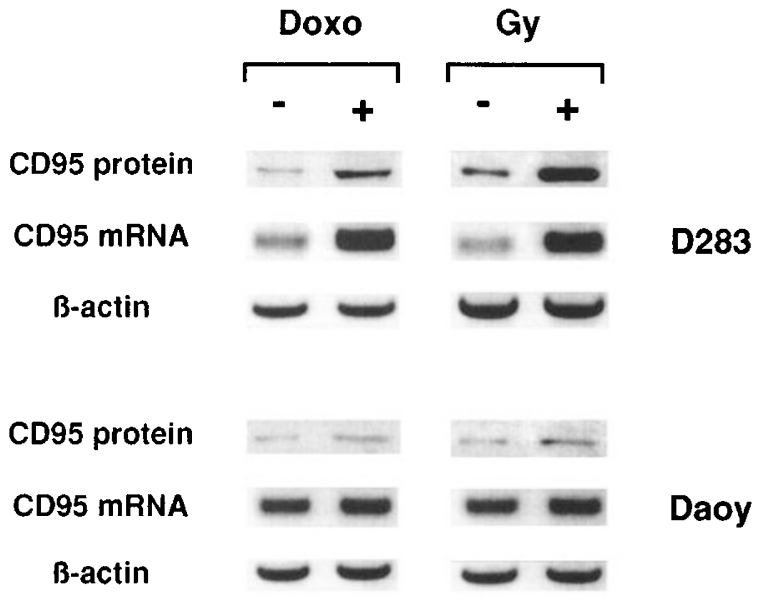

CD95 protein

CD95 mRNA
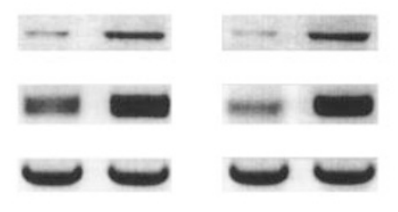
was induced (Figure 5B). FLICE was cleaved to its active subunits and PARP was proteolytically processed (Figure $5 B)$. Moreover, p53 protein strongly accumulated in response to doxorubicin treatment (Figure 5B). Doxorubicin-induced apoptosis was markedly inhibited by cycloheximide and the broad range inhibitor of caspases zVAD-fmk indicating that it depended on protein synthesis and on activation of caspases (data not shown). CD95 expression which was constitutively found in the ex vivo-derived medulloblastoma cells was increased up to fourfold upon incubation with cisplatinum
(Figure 5C). These findings suggest that activation of the CD95 system may also be involved in drug-induced apoptosis in medulloblastoma cells in vivo.

\section{Discussion}

Cytotoxic agents and $\gamma$-irradiation have been described to exert their action on tumor cells, at least in part, by inducing apoptosis (Fisher, 1994; Meyn et al, 1996). However, the molecular mechanisms which determine sensitivity of brain

D
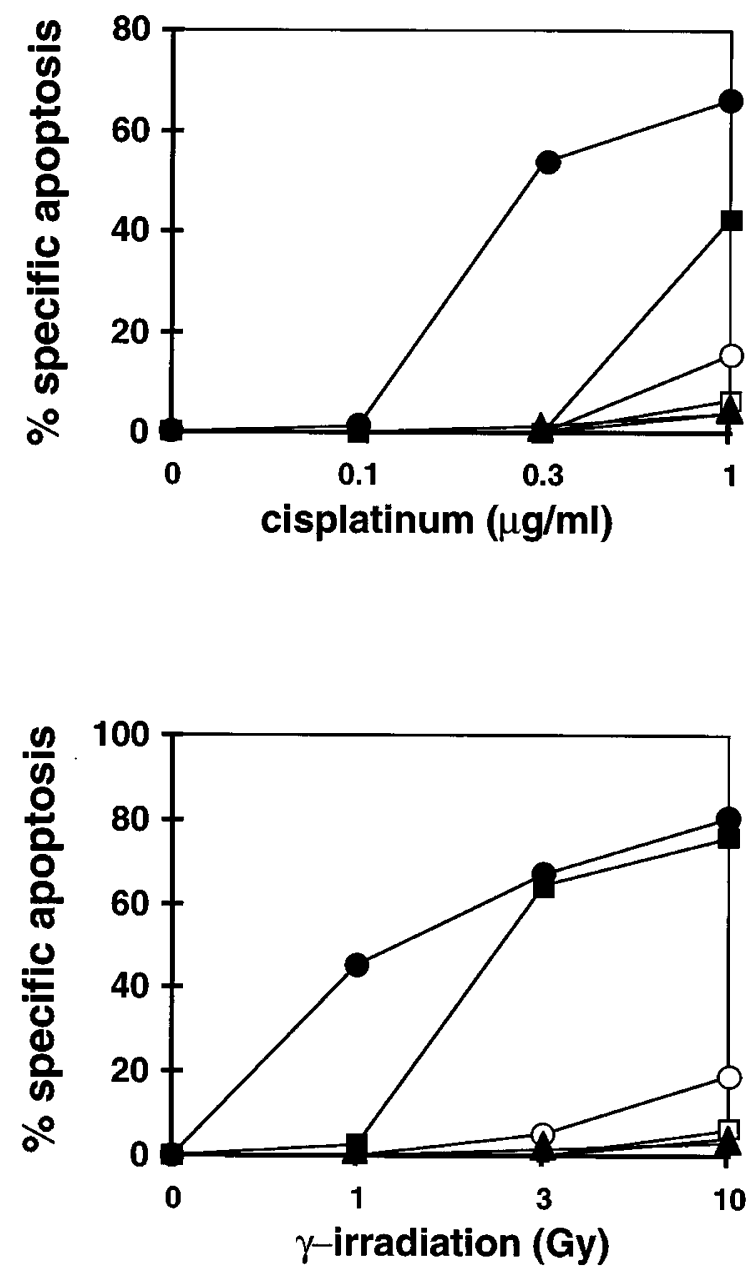

Figure 4 Induction of CD95. (A) Analysis of CD95 protein by FACScan. Medulloblastoma (D283 Med, Daoy) and glioblastoma (A172) cells were treated with $1 \mu \mathrm{g} \mathrm{ml}^{-1}$ cisplatinum or $10 \mathrm{~Gy}$ for $24 \mathrm{~h}$, stained with mouse anti-APO-1 IgG1 monoclonal antibody and analyzed by flow cytometry. Filled curve: treated cells stained with anti-APO-1 antibody, thick line: untreated cells stained with anti-APO-1 antibody, thin line: control cells stained with isotype-matched antibody. Fluorescence intensity (abscissa) is plotted against cell number (ordinate). All experiments were done in triplicates with standard deviations of less than $10 \%$ Similar results were obtained in three separate experiments. (B) Analysis of CD95 mRNA and protein. Medulloblastoma (D283 Med, Daoy) and glioblastoma (A172) cells were treated (+) with $0.1 \mu \mathrm{g} \mathrm{ml}$ doxorubicin (Doxo) or with $10 \mathrm{~Gy}$ (Gy) for $24 \mathrm{~h}$. CD95 mRNA expression was determined by RT - PCR. CD95 protein expression was analyzed by Western blot. $40 \mu \mathrm{g}$ protein of cell lysates per lane were separated by $12 \%$ SDS-PAGE. Immunodetection of CD95 protein was performed by mouse anti-CD95 monoclonal antibody and ECL. (C) Cisplatinum- and $\gamma$-irradiation-induced p53 protein expression. D283 Med medulloblastoma and A172 glioblastoma cells were treated (+) with $1 \mu \mathrm{g} \mathrm{ml}^{-1}$ cisplatinum or $10 \mathrm{~Gy}$ (Gy) for indicated time points. $40 \mu \mathrm{g}$ protein of cell lysates per lane were separated by $12 \%$ SDS-PAGE. Immunodetection of p53 protein was performed by mouse anti-p53 monoclonal antibody and ECL. (D) Increased responsiveness to anti-CD95induced apoptosis after pretreatment with cisplatinum or $\gamma$-irradiation. Medulloblastoma (D283 Med, $\bullet$; Daoy, $\mathbf{\square}$ ) and glioblastoma (A172, $\mathbf{A}$ ) cells were treated with indicated doses of cisplatinum or $\gamma$-irradiation alone for $24 \mathrm{~h}$ and in combination with (closed symbols) or without (open symbols) $1 \mu \mathrm{g} \mathrm{ml} \mathrm{gl}^{-1}$ anti-APO-1 for further $24 \mathrm{~h}$. Apoptosis was determined by FACS analysis of propidium iodide stained nuclei. Specific apoptosis was calculated as described in Figure 1. Specific apoptosis for cells treated for $24 \mathrm{~h}$ with $1 \mu \mathrm{g} \mathrm{ml}^{-1}$ anti-APO-1 alone without cycloheximide was below $4 \%$. Data are given as mean from three independent experiments done in triplicates. Standard deviations were less than $10 \%$ 
tumor cells to treatment have not exactly been defined. Here, we report that activation of the CD95 pathway was involved in drug- and $\gamma$-irradiation-induced apoptosis of medulloblastoma and glioblastoma cells. Upon drug treatment or $\gamma$-irradiation CD95- $L$ was induced and triggered apoptosis in an autocrine or paracrine fashion via its cognate receptor. Interfering with CD95 ligand/receptor interaction by blocking antibodies strongly reduced apoptosis. Drug- and $\gamma$-irradiation-induced apoptosis was mediated by caspases (ICE/Ced-3 like proteases) since the broad spectrum peptide inhibitor of caspases zVAD-fmk almost completely abrogated apoptosis. We recently found that sensitivity for cytotoxic drugs depends on activation of caspases (Los et al, 1997) which have been shown to be an integral part of the CD95 pathway (Los et al, 1995). FLICE has previously been described to be physiologically activated upon CD95 triggering by recruitment to the CD95 DISC (Medema et al, 1997). In this study, we found activation of FLICE upon drug treatment and $\gamma$ irradiation probably mediated via CD95 ligand/receptor interaction. However, $\mathrm{F}\left(\mathrm{ab}^{\prime}\right)_{2}$ anti-APO-1 antibody fragments did not completely block apoptosis. Since we recently found that FLICE was also activated by other death receptors such as TNFR or TRAIL-R (unpublished data), other death receptor/ligand systems in addition to the CD95 system may also be involved. In addition, activation of caspases and cleavage of substrates such as PARP may, to some extent, occur independent of receptor/ligand interaction, e.g. by a direct effect on mitochondria, as indicated by the fact that PARP was already partially cleaved before FLICE cleavage was detected. Doxorubicin-induced activation of caspases and apoptosis was dependent on protein synthesis as it could be inhibited by cycloheximide indicating that activation of caspases and apoptosis were mediated by death-inducing ligands, probably including CD95-L which was induced upon
A

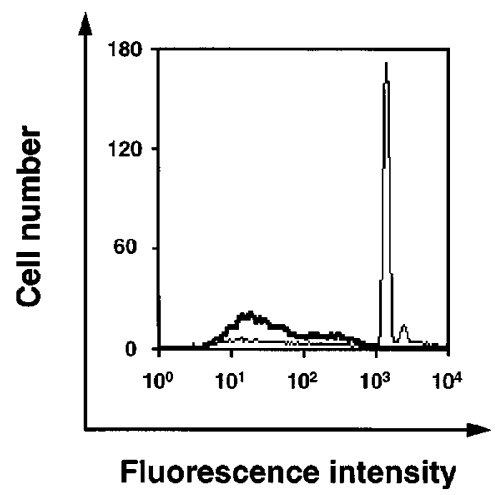

C

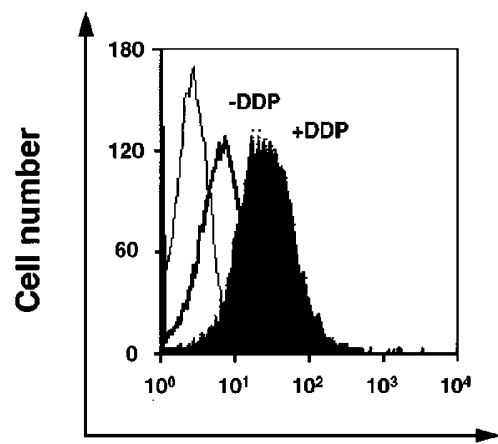

Fluorescence intensity
B

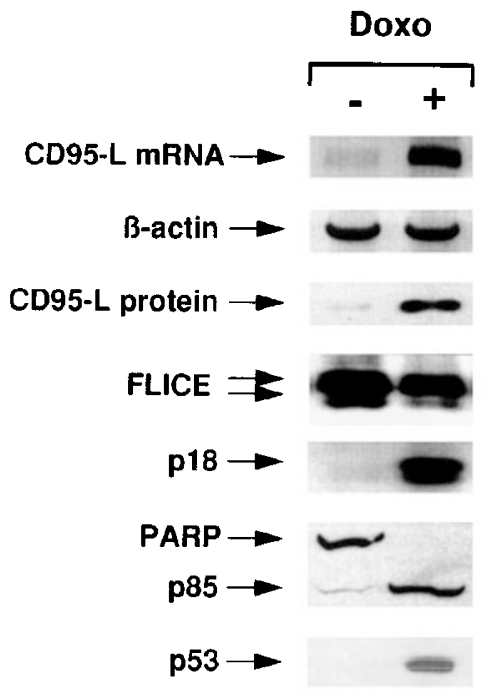

Figure 5 Doxorubicin-induced apoptosis in ex vivo-derived medulloblastoma cells. (A) Doxorubicin-induced apoptosis. Patient's derived medulloblastoma cells were incubated with $0.5 \mu \mathrm{g} \mathrm{ml}^{-1}$ doxorubicin for $24 \mathrm{~h}$. Apoptosis was assessed by FACS analysis of propidium iodide stained nuclei. Thin line: control cells, $16.18 \%$ apoptosis; thick line: cells treated with doxorubicin, $97.3 \%$ apoptosis. Fluorescence intensity (abscissa) is plotted against cell number (ordinate). Experiments were done in duplicates with similar results. (B) Induction of CD95 ligand, activation of caspases and accumulation of p53 protein. Medulloblastoma cells were treated (+) with $0.5 \mu \mathrm{g} \mathrm{ml}^{-1}$ doxorubicin (Doxo) for $12 \mathrm{~h}$ for determination of CD95-L mRNA expression or for $24 \mathrm{~h}$ for Western blot analysis. CD95-L mRNA expression was determined by RT - PCR. Protein expression of CD95-L, FLICE, PARP and p53 was analyzed by Western blot. $40 \mu \mathrm{g}$ protein of cell lysates per lane were separated by $12 \%$ SDS-PAGE. Immunodetection was performed using mouse anti-CD95-L monoclonal antibody, mouse anti-FLICE monoclonal antibody, rabbit anti-PARP polyclonal antibody or mouse ant-CPP32 monoclonal antibody and ECL. (C) Induction of CD95. Medulloblastoma cells were treated with $1 \mu \mathrm{g}$ ml ${ }^{-1}$ cisplatinum for $15 \mathrm{~h}$, stained with mouse anti-APO-1 lgG1 monoclonal antibody and analyzed by flow cytometry. Filled curve: treated cells stained with anti-APO-1 antibody (+DDP), thick line: untreated cells stained with anti-APO-1 antibody (-DDP), thin line: control cells stained with isotype-matched antibody. Fluorescence intensity (abscissa) is plotted against cell number (ordinate). Experiments were done in duplicates with similar results 
drug treatment. Taken together, these results show that an intact CD95 signaling pathway was necessary for proper propagation of the death signal. Since activation of the CD95 system upon drug treatment was not restricted to cell lines, but also found in primary tumor cells, our findings are probably relevant to the in vivo situation. However, since most malignant gliomas in vivo are rather resistant to treatment (Deen et al, 1993), anti-apoptotic programs may be involved in regulation of apoptosis in these tumors (Weller et al, 1995).

There are previous reports on induction of ICE expression after cisplatinum treatment in malignant glioma cells (Kondo et al, 1995) and on PARP cleavage following chemotherapy and $\gamma$-irradiation (Kaufmann et al, 1993; Datta et al, 1997). In addition to these reports our findings show that cleavage of caspases and PARP following drug treatment and $\gamma$-irradiation involves activation of the CD95 system. Drug concentrations used in this study correspond to plasma levels which can be achieved in patients following chemotherapy (Muller et al, 1993; Dominici et al, 1989) indicating that our findings may be of therapeutical relevance. We previously identified stimulation of the CD95 system as one mechanism leading to apoptosis in leukemia and neuroblastoma cells in response to drug treatment (Friesen et al, 1996; Fulda et al, 1997). In the present study, we found activation of the CD95 system in medulloblastoma and glioblastoma cells sensitive to chemotherapy and $\gamma$-irradiation. Thus, apoptosis mediated by the CD95 system might play an important role for cytotoxicity by different stimuli such as anticancer drugs and $\gamma$-irradiation in a variety of sensitive tumor cells. Involvement of the CD95 system in radiation-induced apoptosis has recently been described (Reap et al, 1997). However, recent reports also suggest that alternative signaling pathways may be involved in drug-triggered apoptosis in some cell types (Eischen et al, 1997; Villunger et al, 1997).

Wild-type p53 accumulates in response to DNA damage (Fisher, 1994). Upon drug incubation and $\gamma$-irradiation we found upregulation of CD95 following accumulation of p53 in wild-type p53 cells, but not in p53 mutant cells consistent with previous reports (Owen-Schaub et al, 1995; Mueller et al, 1997). Expression of both CD95 mRNA and CD95 protein was increased suggesting that upregulation of CD95 might be regulated by p53 at the transcriptional level or by its influence on stability of CD95 mRNA. Since upregulation of CD95 enhanced sensitivity of these cells to anti-CD95 triggering, it might be functionally important during drug- and $\gamma$-irradiation-induced apoptosis which involved CD95 ligand/receptor interaction.

There are conflicting data on the relation of p53 status and sensitivity of cancer cells to treatment-induced cytotoxicity. Loss of p53 function is usually considered to confer resistance to chemotherapy and radiation (Lowe et al, 1993) and mutations of the p53 gene although uncommon in childhood medulloblastoma and gliomas have been associated with poor in vivo chemosensitivity and a less favorable prognosis (Pollak et al, 1997; Saylors et al, 1991). However, recent evidence suggests that the cytotoxic response to chemotherapeutic agents might be variably modulated by loss of wild-type p53 function and might be tissue-specific (Cote et al, 1997; Wahl et al, 1995). In addition, p53-independent pathways have also been described (Haas-Kogan et al, 1996; Lieberman et al, 1995). We found a similar response to treatment in p53 mutant Daoy medulloblastoma cells compared to wild-type p53 medulloblastoma and glioblastoma cells. Thus, the p53 status per se might not always be a good predictor for treatment response and intact apoptosis pathways in a more general sense may determine sensitivity or resistance of tumor cells.

These findings may have important implications for the future management of medulloblastoma and malignant glioma. Insights into the molecular components which determine sensitivity to treatment may provide a solid basis for new treatment approaches, i.e. the development of novel compounds or gene transfer approaches to increase sensitivity and to overcome resistance.

\section{Materials and Methods}

\section{Drugs and irradiation protocol}

Doxorubicin (Farmitalia, Milano, Italy) and cisplatinum (Sigma, Deisenhofen, Germany) were provided as pure substances and dissolved in sterile water $\left(1 \mathrm{mg} \mathrm{ml}^{-1}\right)$. Cells were irradiated with doses of 3-100 Gy at room temperature using a ${ }^{137} \mathrm{Cs}$ source (Gamma Cell 1000, Atomic Energy of Canada, Ltd., ON) at $1.3 \mathrm{~Gy} / \mathrm{min}$.

\section{Cell culture and preparation of medulloblastoma tumor specimen}

Human medulloblastoma cell lines Daoy (Jacobsen et al, 1985) and D283 Med (Friedman et al, 1985) and the glioblastoma cell line A172 (Giard et al, 1973) were obtained from the American Type Culture Collection (Rockville, MD) and maintained in monolayer culture in $75 \mathrm{~cm}^{2}$ tissue culture flasks (Falcon, Heidelberg, Germany) in RPMI 1640 medium (Gibco BRL, Eggenstein, Germany) supplemented with $10 \%$ heat inactivated FCS (Conco, Wiesbaden, Germany), $10 \mathrm{mM}$ HEPES, pH 7.3 (Biochrom, Berlin, Germany), $100 \mathrm{U} \mathrm{ml}^{-1}$ penicillin (Gibco), $100 \mu \mathrm{g} / \mathrm{ml}^{-1}$ streptomycin (Gibco) and $2 \mathrm{mM} \mathrm{L-glutamine}$ (Biochrom) and incubated at $37^{\circ} \mathrm{C}$ in $95 \%$ air $/ 5 \% \quad \mathrm{CO}_{2}$. Primary medulloblastoma tumor tissue containing more than $95 \%$ of tumor cells as assessed by histological examination was obtained at the time of initial surgery from a 10-year-old boy. Classical histology of a medulloblastoma WHO grade IV with no evidence for neuronal or glial differentiation was found.

\section{Determination of apoptosis}

FACS analysis of propidium iodide stained nuclei was performed as previously described (Nicoletti et al, 1991). Cells were analyzed for DNA content by flow cytometry (FACScan, Becton Dickinson, Heidelberg, Germany) using CELLQuest software.

\section{Inhibition of apoptosis by zVAD-fmk, CHX or $F\left(a b^{\prime}\right)_{2}$ anti-APO-1 (anti-CD95) antibody fragments}

The broad range tripeptide inhibitor of caspases zVAD-fmk (Enzyme Systems Products, Dublin, CA) was used at a concentration of $60 \mu \mathrm{M}$. Preparations of $F\left(a b^{\prime}\right)_{2}$ anti-APO-1 (CD95) antibody fragments and isotype-matched antibody FII23 (IgG3) were performed as previously described (Dhein et al, 1995). Cells were incubated with $10 \mu \mathrm{g} \mathrm{ml}^{-1}$ 
$\mathrm{F}\left(\mathrm{ab}^{\prime}\right)_{2} 0.5 \mu \mathrm{g} \mathrm{ml}^{-1} \mathrm{CHX}$ (Sigma) for $1 \mathrm{~h}$ at $37^{\circ} \mathrm{C}$ prior to addition of drugs.

\section{Detection of CD95 expression}

Cells were stained with anti-APO-1 (anti-CD95) IgG1 monoclonal antibody $\left(1 \mu \mathrm{g} \mathrm{ml}^{-1}\right)$ (Trauth et al, 1989) for $45 \mathrm{~min}$ at $4^{\circ} \mathrm{C}$ followed by goat anti-mouse IgG-phycoerythrin (Immunotech, Hamburg, Germany) for 30 min at $4^{\circ} \mathrm{C}$. Cells were analyzed by flow cytometer using CELLQuest software (Becton Dickinson). FII23 IgG1 antibody was used as isotype-matched antibody to control unspecific binding.

\section{RT - PCR for CD95 and CD95-L mRNA}

Total RNA was prepared using the Qiagen total RNA kit (Qiagen, Hildren, Germany). RNA was converted to cDNA by reverse transcription and amplified for 38 cycles by PCR in a thermocycler (Stratagene, Heidelberg, Germany) using the Gene Amplification RNA-PCR kit (Perkin Elmer, Branchburg, NJ) following the manufacturer's instructions. A 500-base pair fragment of CD95-L was amplified using primer $5^{\prime}$-ATGTTTCAGCTCTTCCACCTACAGA$3^{\prime}$ and 5'-CCAGAGAGAGCTCAGATACGTTGAC-3' and a 311-base pair fragment of CD95 was amplified using primer $5^{\prime}$-TCAAGGAATGCACACTCACCAGC and 5'-GGCTTCATTGACACCATTCTTTCG-3'. Expression of $\beta$-actin (MWG-Biotech, Ebersberg, Germany) was used as standard for RNA integrity and equal gel loading. PCRreaction products were run at $60 \mathrm{~V}$ for $2 \mathrm{~h}$ on a $1.5 \%$ agarose gel stained with ethidium bromide and visualized by UV illumination.

\section{Western blot analysis}

Proteins for Western blot analysis were extracted from cells lysed for $30 \mathrm{~min}$ at $4{ }^{\circ} \mathrm{C}$ in PBS with $0.5 \%$ Triton $X$ (Serva) and $1 \mathrm{mM}$ PMSF (Sigma) followed by high-speed centrifugation. Membrane proteins were eluted by buffer containing $0.1 \mathrm{M}$ glycine, $\mathrm{pH} 3.0$ and $1.5 \mathrm{M}$ Tris, $\mathrm{pH}$ 8.8. Protein concentration was assayed using bicinchoninic acid (Pierce, Rockford, IL). $40 \mu \mathrm{g}$ protein per lane was separated by $12 \%$ SDS-PAGE and electroblotted onto nitrocellulose (Amersham, Braunschweig, Germany). Equal protein loading was controlled by Ponceau red staining of membranes. After blocking for $1 \mathrm{~h}$ in PBS supplemented with 2\% BSA (Sigma) and $0.1 \%$ Tween 20 (Sigma) immunodetection of CD95-L, CD95, FLICE, CPP32, PARP and p53 protein was done using mouse antiCD95-L monoclonal antibody $(1: 2500$, Transduction Laboratories, Lexington, KY), mouse anti-CD95 monoclonal antibody (1:1000, Transduction Laboratories), mouse anti-FLICE monoclonal antibody C15 recognizing the FLICE active subunits p18 (1:5 dilution of hybridoma supernatant, Scaffidi et al, 1997), mouse anti-CPP32 monoclonal antibody (1:1000, Transduction Laboratories), rabbit anti-PARP polyclonal antibody $(1: 5000$, Enzyme Systems Products) or mouse anti-p53 monoclonal antibody (1:1000, Transduction Laboratories) followed by horseradish peroxidase-conjugated goat anti-mouse IgG or goat anti-rabbit IgG (1:5000, Santa Cruz Biotechnology, Santa Cruz, CA). ECL (Amersham) was used for detection.

\section{Acknowledgements}

We thank U. Silberzahn for expert technical assistance. This work was supported by grants from the Deutsche Forschungsgemeinschaft (K-MD, MEP, PHK, TP), the Bundesministerium für Forschung and Technologie, Bonn, the Tumor Center Heidelberg/Mannheim and the Deutsche Leukämieforschungshilfe.

\section{References}

Cote RJ, Esrig D, Groshen S, Jones PA and Skinner DG (1997) p53 and treatment of bladder cancer. Nature 385: 123-125

Datta R, Kojima H, Banach D, Bump NJ, Talanian RV, Alnemri ES, Weichselbaum RR, Wong WW and Kufe DW (1997) Activation of a CrmA-insensitive, p53sensitive pathway in ionizing radiation-induced apoptosis. J. Biol. Chem. 272: $1965-1969$

Debatin KM (1996) Disturbances of the CD95 (APO-1/Fas) system in disorders of lymphohaematopoietic cells. Cell Death Differ. 3: 185-189

Debatin KM (1997) Cytotoxic drugs, cell death and the immune system: defining new roles in an old play. J. Natl. Cancer Inst. 89: 750-751

Deen DF, Chiarodo A, Grimm EA, Fike JR, Israel MA, Kun LE, Levin VA, Marton LJ, Packer RJ and Pegg AE (1993) Brain tumor working group report on the 9th international conference on brain tumor research and therapy. J. Neurooncol. 16: 243-272

Dhein J, Walczak H, Baeumler C, Debatin KM and Krammer PH (1995) Autocrine Tcell suicide mediated by APO-1 (Fas/CD95). Nature 373: 438-441

Dominici C, Petrucci F, Caroli S, Alimonti A, Clerico A and Castello MA (1989) A pharmacokinetic study of high-dose continuous infusion cisplatin in children with solid tumors. J. Clin. Oncol. 7: 100-107

Eischen CM, Kottke TJ, Martins LM, Basi GS, Tung JS, Earnshaw WC, Leibson PJ and Kaufmann SH (1997) Comparison of apoptosis in wild-type and Fasresistant cells: chemotherapy-induced apoptosis is not dependent on Fas/Fas ligand interactions. Blood 90: 935-943

Fisher DE (1994) Apoptosis in cancer therapy: crossing the threshold. Cell 78: 539 542

Friedman HS, Oakes WJ, Bigner SH, Wikstrand CJ and Bigner DD (1991) Medulloblastoma: tumor biological and clinical perspectives. J. Neurooncol. 11: $1-15$

Friedman HS, Burger PC, Bigner SH, Trojanowski JQ, Wikstrand CJ, Halperin EC and Bigner DD (1985) Establishment and characterization of the human medulloblastoma cell line and transplantable xenograft D283. Med. J. Neuropathol. Exp. Neurol. 44: 592-605

Friesen C, Herr I, Krammer PH and Debatin KM (1996) Involvement of the CD95 (APO-1/Fas) receptor/ligand system in drug-induced apoptosis in leukemia cells. Nat. Med. 2: $574-577$

Fulda S, Sieverts H, Friesen C, Herr land Debatin KM (1997) The CD95 (APO-1/Fas) system mediates drug-induced apoptosis in neuroblastoma cells. Cancer Res. 57: $3823-3829$

Giard DJ, Aaronson SA, Todaro GJ, Arnstein P, Kersey JH, Dosik H and Parks W (1973) In vitro cultivation of human tumors: establishment of cell lines derived from a series of solid tumors. J. Natl. Cancer Inst. 51: $1417-1421$

Haas-Kogan DA, Yount G, Haas M, Levi D, Kogan SS, Hu L, Vidair C, Deen DF, Dewey WC and Israel MA (1996) p53-dependent G1 arrest and p53-independent apoptosis influence the radiobiologic response of glioblastoma. Int. J. Radiat. Oncol. Biol. Phys. 36: 95-103

Jacobsen PF, Jenkyn DJ and Papadimitriou JM (1985) Establishment of a human medulloblastoma cell line and its heterotransplantation into nude mice. J. Neuropathol. Exp. Neurol. 44: 472-485

Kaufmann SH, Desnoyers S, Ottaviano Y, Davidson NE and Poirier GG (1993) Specific proteolytic cleavage of poly(ADP-ribose) polymerase: an early marker of chemotherapy-induced apoptosis. Cancer Res. 53: 39763985

Kischkel FC, Hellbardt S, Behrmann I, Germer M, Pawlita M, Krammer PH and Peter ME (1995) Cytotoxicity-dependent APO-1 (Fas/CD95)-associated proteins form a death-inducing signaling complex (DISC) with the receptor. EMBO J. 14: $5579-5588$

Kondo S, Barna BP, Morimura T, Takeuchi J, Yuan J, Akbasak A and Barnett GH (1995) Interleukin-1 $\beta$-converting enzyme mediates cisplatin-induced apoptosis in malignant glioma cells. Cancer Res. 55: 6166-6171

Krammer PH, Dhein J, Walczak H, Behrmann I, Mariani S, Matiba B, Fath M, Daniel PT, Knipping E, Westendorp MO and Debatin KM (1994) The role of APO-1-mediated apoptosis in the immune system. Immunol. Rev. 142: $175-191$

LiebermanN DA, Hoffman B and Steinman RA (1995) Molecular controls of growth arrest and apoptosis: p53-dependent and independent pathways. Oncogene 11: 199-210 
Los M, Herr I, Friesen C, Fulda S, Schulze-Osthoff K and Debatin KM (1997) Crossresistance of CD95- and drug-induced apoptosis as a consequence of deficient activation of caspases (ICE/Ced-3 proteases). Blood 90: 3118-3129

Los M, Van de Craen M, Penning LC, SchenkH, Westendorp M, Baeuerle P, Droge W, Krammer PH, Fiers W and Schulze-Osthoff K (1995) Requirement of an ICE/ Ced-3 protease for Fas/APO-1-mediated apoptosis. Nature 375: 81-83

Lowe SW, Ruley HE, Jacks T and Housman DE (1993) p53-dependent apoptosis modulates the cytotoxicity of anticancer agents. Cell 74: 957-967

Matusomoto H, Shimura M, Omatsu T, Okaichi K, Majima Hand Ohnishi (1994) Tp53 proteins accumulated by heat stress associate with heat shock proteins HSP72/ HSC73 in human glioblastoma cell lines. Cancer Lett. 87: 39-46

Medema JP, Scaffidi C, KischkelFC, Shevchenko A, Mann M, KrammerPH and Peter ME (1997) FLICE is activated by association with the CD95 death-inducing signaling complex (DISC). EMBO J. 16: 2794-2804

Meyn RE, Stephens LC and Milas L (1996) Programmed cell death and radioresistance. Cancer Metastasis Rev. 15: 119-131

Michaeu O, Solary E, Hammann A, Martin F and Dimanche-Boitrel MT (1997) Sensitization of cancer cells treated with cytotoxic drugs to Fas-mediated cytotoxicity. J. Natl. Cancer Inst. 89: 783-789

Muller C, ChatelutE, Gualano V, De Forni M, HuguetF, Attal M, Canal P and Laurent G (1993) Cellular pharmacokinetics of doxorubicin in patients with chronic lymphocytic leukemia: comparison of bolus administration and continuous infusion. Cancer Chemother. Pharmacol. 32: 379-384

Mueller M, Strand S, Hug H, Heinemann EM, Walczak H, Hofmann WJ, Stremmel W, Krammer PH and Galle PR (1997) Drug-induced apoptosis in hepatoma cells is mediated by the CD95 (APO-1/Fas) receptor/ligand) system and involves activation of wild-type p53. J. Clin. Invest. 99: 403-413

Muzio M, Chinnaiyan AM, Kischkel FC, O'Rourke K, Shevchenko A, Ni J, Scaffidi C, Bretz JD, Zhang M, Gentz R, Mann M, Krammer PH, Peter ME and Dixit VM (1996) FLICE, a novel FADD-homologous ICE/CED-3-like protease, is recruited to the CD95 (Fas/APO-1) death-inducing signaling complex. Cell 85: 817-827

Nagata S (1997) Apoptosis by death factor. Cell 88: 355-365

Nicoletti I, Migliorati G, Pagliacci MC, Grignani F and Riccardi C (1991) A rapid and simple method for measuring thymocyte apoptosis by propidium iodide staining and low cytometry. J. Immunol. Methods 139: 271-279

Oehm A, Behrmann I, Falk W, Pawlita M, Maier G, Klas C, Li Weber M, Richards S, Dhein J, Trauth BC, Ponstingl $\mathrm{H}$ and Krammer PH (1992) Purification and molecular cloning of the APO-1 cell surface antigen, a member of the tumor necrosis factor/nerve growth factor receptor superfamily. J. Biol Chem. 267: $10709-10715$

Owen-Schaub LB, Zhang W, CusackJC, Angelo LS, Santee SM, Fujiwara T, Roth JA, Deisseroth AB, Zhang WW, Kruzel E and Radinsky R (1995) Wild-type human p53 and a temperature-sensitive mutant induce Fas/APO-1 expression. Mol. Cell. Biol. 15: 3032-3040

Peter ME, Kischkel FC, Hellbardt S, Chinnaiyan AM, Krammer PH and Dixit VM (1996) CD95 (APO-1/Fas)-associating signaling proteins. Cell Death Differ. 3: $161-170$
Pollack IF, Hamilton RL, Finkelstein SD, Campell JW, Martinez AJ, Sherwin RN Bozik ME and Gollin SM (1997) The relationship between tp53 mutations and overexpression of $\mathrm{p} 53$ and prognosis in malignant gliomas of childhood. Cancer Res. 57: 304-309

Reap EA, Roof K, Maynor K, Borrero M, Booker J and Cohen PL (1997) Radiation and stress-induced apoptosis: a role for Fas/Fas ligand interaction. Proc. Natl. Acad Sci. USA 94: $3750-3755$

Saylors RL, Sidransky D, Friedman HS, Bigner SH, Bigner DD, Vogelstein B and Brodeur GM (1991) Infrequent p53 gene mutations in medulloblastoma. Cancer Res. 51: $4721-4723$

Scaffidi C, Medema JP, Krammer PH and Peter ME (1997) FLICE is predominantly expressed as two functionally active isoforms, caspase-8/a and caspase-8/b. J. Biol. Chem. 272: 26953-26958

Stevens MC, Cameron AH, Muir KR, Parkes SE, Reid H and Whitwell H (1991) Descriptive epidemiology of primary central nervous system tumors in children: a population-based study. Clin. Oncol. R. Coll. Radiol. 3: 323-329.

Suda T, Takahashi T, Golstein P and Nagata S (1993) Molecular cloning and expression of the Fas ligand, a novel member of the tumor necrosis factor family. Cell 75: $1169-1178$

Tanaka M, Suda T, Takahashi T and Nagata S (1995) Expression of the functional soluble form of human Fas ligand in activated lymphocytes. EMBO J. 14:11291135

Tewari M, Quan LT, O'Rourke K, Desnoyers S, Zeng Z, Beidler DR, Poirier GG, Salvesen GS and Dixit VM (1995) Yama/CPP32 $\beta$, a mammalian homolog of Ced3 , is a CrmA-inhibitable protease that cleaves the death substrate poly(ADP. ribose) polymerase. Cell 81: 801-809

Thompson CB (1995) Apoptosis in the pathogenesis and treatment of disease. Science 267: $1456-1462$

Trauth BC, Klas C, Peter AM, Matzku S, Moeller P, Falk W, Debatin KM and Krammer PH (1989) Monoclonal antibody-mediated tumor regression by induction of apoptosis. Science 245: 301-305

Villunger A, Egle A, Kos M, Hartmann BL, Geley S, Kofler R and Greil R (1997) Druginduced apoptosis is associated with enhanced Fas (APO-1/CD95) ligand expression but occurs independently of Fas (APO-1/CD95) signaling in human T-cute lymphatic leukemia cells. Cancer Res. 57: 3331-3334

Wahl AF, Donaldson KL, Fairchild C, Lee FY, Foster SA, Demers GW and Galloway DA (1996) Loss of normal p53 function confers sensitization to Taxol by increasing G2/M arrest and apoptosis. Nat. Med. 2: 72-79

Weller M, Malipiero U, Aguzzi A, Reed JC and Fontana A (1995) Protooncogene bcl-2 gene transfer abrogates Fas/APO-1 antibody-mediated apoptosis of human malignant glioma cells and confers resistance to chemotherapeutic drugs and therapeutic irradiation. J. Clin. Invest. 95: 2633-2643

Weller M, Frei K, Groscurth P, Krammer PH, Yonekawa Y and Fontana A (1994) AntiFas/APO-1 antibody mediated apoptosis of cultured human glioma cells. Induction and modulation of sensitivity by cytokines. J. Clin. Invest. 94: 954-964 